\title{
Islam, stat og demokrati i Tyrkia
}

Fortjener det tyrkiske demokratiet å bli holdt frem som et eksempel til etterfølgelse for andre muslimske stater? Og hvor relevant er nasjonens muslimske identitet for videre demokratisering i Tyrkia i dag?

Av Wilhelm Kavli, tidligere universitetslektor i internasjonal politikk, Hacettepe üniversitesi, Ankara.

Det siste tiåret har det tyrkiske demokratiet til stadighet blitt holdt frem som et demokratisk eksempel til etterfølgelse for andre muslimske stater, som regel uten noen refleksjon over dette demokratiets stilling og dets bakgrunn. Derfor kan det være betimelig å spørre i hvilken grad det tyrkiske demokratiet fortjener å bli holdt frem som et slikt eksempel. Likeledes er det verdt å sette spørsmålstegn ved hvor relevant nasjonens muslimske identitet har vært for det tyrkiske demokratiet, og om det er islam eller andre faktorer som holder igjen videre demokratisering i landet.

Denne artikkelen søker å belyse disse spørsmålene, ved å analysere stillingen for Tyrkias demokrati i dag i lys av sider ved den politiske historien og den aktuelle politiske situasjonen i landet. Første del gir et raskt overblikk over bakgrunnen for det tyrkiske demokratiet frem til Partiet for rettferdighet og fremskritt - Adalet ve Kalkınma Partisi (AKP) tok over regjeringsmakten etter parlamentsvalget i 2002 . Annen del ser på AKP som et politisk fenomen, og fokuserer på partiets stilling mellom islamisme og sekularisme. Tredje del tar for seg begrensningene ved demokratiets stilling i Tyrkia i dag, og diskuterer et knippe mulige forklaringer på disse. Avslutningsvis holdes analysen av demo- kratiets stilling i dagens Tyrkia opp mot utbredte forestillinger om at islam utgjør en hemsko for etableringen av et liberalt demokrati.

\section{Det tyrkiske demokratiets utgangspunkt}

Den tyrkiske republikken som ble etablert etter Det osmanske rikets fall innførte snart en «demokratisk ettpartistat», med allmenn stemmerett for både kvinner og menn. Dette var en del av et radikalt og ambisiøst moderniseringsprosjekt, som skulle transformere det akterutseilte og utarmede tyrkiske samfunnet til en moderne europeisk nasjonalstat. Landsfaderen Mustafa Kemal Atatürks mål var å gi den tyrkiske nasjonen en plass i Europa, på linje med de europeiske stormaktene.

På det politiske området var Frankrike den viktigste referansen i denne prosessen, og man importerte en rekke statsprinsipper fra den franske tradisjonen, deriblant etatismen og sekularismen. Den nye eliten søkte å ta kontroll over de religiøse institusjonene, dels ved inkorporering og dels ved forbud. Samtidig prøvde man å benytte den statskontrollerte religionen som en sosial og politisk mobiliseringsfaktor.

Dette moderniseringsprosjektet ble initiert og implementert ovenfra, men regimet var opptatt av å sikre reformene folkelig 
legitimitet. Selv om prosjektets mål nøt bred folkelig støtte, ble mange av reformene mottatt som påtvunget europeisering. Disse skapte naturlig nok motstand i brede lag av folket.

Regimet var i denne første reformperioden i realiteten autoritært, men representantene i parlamentet bidro likevel i de politiske prosessene. Selv om dette ikke var et genuint demokratisk styre, bidro de demokratiske institusjonene utvilsomt både hjemme og ute til regimets legitimitet. I Europa var dette en tid preget av økonomisk ustabilitet, klassekamp og fascisme; kun en håndfull europeiske stater klarte å opprettholde et troverdig demokrati gjennom hele mellomkrigstiden.

Men reell demokratisk konkurranse om Tyrkias statsmakt fikk man først etter andre verdenskrig. Atatürks arvtager Ismet Inönü sto da overfor klare føringer, både fra sin avdøde forgjenger og fra kommende alliansepartnere i NATO. Det statsbærende Republikanske folkepartiet - Cumhuriyet Halk Partisi (CHP) - ble delt i to, og det ble dermed åpnet for et flerpartisystem med parlamentarisme. Det nyetablerte opposisjonspartiet vant overraskende parlamentsvalget i I950, på et program som i stor grad gikk ut på å moderere de radikale reformene som hadde utgjort Atatürks moderniseringsprogram. Men Inönü respekterte valgresultatet, og ga fra seg makten.

Allerede i I960 satte imidlertid militæret landets demokratiske system ut av spill gjennom et kupp. Den militærbyråkratiske eliten i Ankara identifiserte seg med Atatürks moderniseringsprosjekt og CHP, som hadde blitt skjøvet ut i opposisjon. Denne eliten hadde vært lite begeistret for det den så som regjeringspartiets reaksjon- ære politikk, og dets manglende respekt for konstitusjonen som hadde brakt det til makten åtte år tidligere. Eliten i Ankara forklarte kuppet som et forsvar av arven fra landsfader Atatürk. Men i stedet for å beholde makten, lot offiserene demokratiet gjenetableres med en ny konstitusjon i I962.

Nye politiske kriser ble møtt med nye militærkupp, i I97I og I980. Begge ganger gjenopprettet offiserene sivilt styre. Etter det siste av disse kuppene ville imidlertid generalene gå hardere til verks for å bryte den onde sirkelen av politiske kriser og kupp. Deres oppskrift var å avpolitisere studentene, universitetene og organisasjonslivet. En rekke sivile og politiske rettigheter ble begrenset. Dogmatisk nasjonalisme skulle erstatte ideologisk polarisering, ensretting skulle erstatte fraksjonering.

I skyggen av konflikten mellom sosialister og nasjonalister hadde politisk islam siden sekstitallet vokst frem under Necmettin Erbakans ledelse. Denne utfordringen ble etter i980 forsøkt inkorporert i den nye nasjonalismen. President Turgut Özals styre fra I983-91 kombinerte liberalisme og tradisjonalistisk populisme. Dette åpnet ifølge Hakan Yavuz for en bølge av islamsk pluralisme. Toleransen for islamistene varte frem til midten av nittitallet, da det ble klart at politisk islam ikke lot seg nøytralisere på denne måten.

For å unngå politisk fragmentering og sikre styringsdyktige regjeringer, ble sperregrensen for partier ved valg til parlamentet i konstitusjonen av I982 satt til hele ti prosent. Generalene prøvde med dette å tvinge frem en topartimodell som i USA, uten å lykkes. Men reformene lyktes likevel i stor grad i å avpolitisere kommende generasjoner, og forsterket nasjonal- 
ismen som politikkens språk. Som man kunne forvente, førte det til at mye av den gjenværende politiske debatten i Tyrkia har dreid seg om hva innholdet i denne nasjonalismen skal være. Denne prosessen skapte ny motstand, som vokste opp utenfor det trange politiske rommet definert av generalenes nye konstitusjon.

\section{Radikale utfordrere}

I årene som fulgte ble dette nasjonalistiske politiske landskapet utfordret utenfra fra tre ulike retninger. Hver av disse fikk både sivile og militante uttrykk, som ikke nødvendigvis hadde noen forbindelse med hverandre. Den første av de tre retningene var den kurdiske bevegelsen, med kurdiske politiske partier og den militante separatistbevegelsen Parti Karkerani Kurdistan (PKK) og andre kurdiske militante grupper. Den andre radikale utfordreren var den radikale venstresiden, med marginale Det tyrkiske kommunistpartiet - Türkiye Komünist Partisi (TKP), samt en rekke ekstreme og mer eller mindre militante grupper. Den tredje var islamistene, med deres politiske partier og militante uttrykk som tyrkiske Hizbullah og andre militante grupper.

De politiske partiene til disse tre radikale utfordrerne har alle blitt anklaget for å bryte konstitusjonen, og blitt stengt av konstitusjonsdomstolen. De er imidlertid gang på gang blitt reetablert under nye navn. Islamistene fikk regjeringsmakt i allianse med et konvensjonelt parti på høyresiden etter å ha gjort et godt valg i I995, men ble presset ut av regjering etter påtrykk fra militæret i I997, for så å bli stengt året etter. Militante grupper fra alle de tre radikale ideologiske utgangspunktene har på sin side utført tallrike terroraksjoner mot sivile mål. PKK kastet deler av landet ut $\mathrm{i}$ en borgerkrigslignende tilstand som varte til langt ut på nittitallet.

\section{AKP mellom sekularisme og islamisme}

For å i det hele tatt kunne forstå den politiske utviklingen $\mathrm{i}$ dagens Tyrkia og religionens rolle i politikken i muslimske samfunn, må man skille mellom sekularisme som statsprinsipp og statsideologi på den ene siden, og sekularisering som sosial prosess på den andre. Et nærliggende eksempel kan være Norge, som fremdeles ikke er en sekulær stat, og hvor sekularisme som ideologi står forholdsvis svakt. Samtidig er det norske samfunnet blant de mest sekulariserte i verden. I USA er forholdet grovt sett omvendt, med en sekulær stat og en sekularistisk statsideologi, men et langt mindre sekularisert samfunn.

Som vi skal se har Tyrkia her mer til felles med USA, med den viktige forskjellen at den etatistiske tyrkiske varianten av sekularisme som statsideologi nå er satt under et sterkt press fra periferien i det tyrkiske samfunnet. Men dette innebærer ikke nødvendigvis at sekularisme som statsprinsipp står for fall i Tyrkia.

Det tyrkiske parlamentsvalget i november 2002 har med rette blitt betegnet som et politisk jordskjelv. Partiet for rettferdighet og fremskritt - Adalet ve Kalkınma Partisi (AKP) vant en klar seier under ledelse av den populære politikeren Recep Tayyıp Erdogan. AKP hadde blitt stiftet bare I5 måneder tidligere, som ett av to etterfølgerpartier etter Erbakans islamistisk inspirerte Dydspartiet - Fazilet Partisi (FP). FP var blitt stengt sommeren 200I, i en dom der partiet ble dømt for å handle i strid med statens sekulære identitet.

Det var Erbakans Lykksalighetspartiet - 
Saadet Partisi (SP) - som videreførte dets program, mens Erdogans AKP overtok brorparten av partiets velgere. Erdogan ble her godt hjulpet av sitt omdømme som en oppriktig og ærlig muslim, og har spilt uhemmet på dette. Partiet er blant sine tilhengere kjent som «AK-parti»; «ak» kan på tyrkisk bety både lys, ren og ærlig. Partiets symbol er en lysende lyspære, som skal bringe lys inn i politikkens dunkle kroker. Mange velgere på den sekularistiske siden opplevde høsten 2002 at republikkens sekulære natur og grunnleggende sivile friheter sto på spill. Men for flertallet av dem som faktisk stemte på AKP var valget et oppgjør med det de betraktet som politikere uten vilje eller evne til å styre landet på ansvarlig vis. Erdogan ga moderate tyrkiske velgere et tydelig alternativ til en stagnert venstreside og en korrumpert høyreside.

Flertallet av partiets velgere i 2002 så altså ikke Erdogan som Erbakans ideologiske etterfølger. Der Erbakan avviste den vestlige moderniteten og søkte mot den muslimske verden, søkte Erdogan fra etableringen av AKP aktivt å forene den vestlige moderniteten med tradisjonelle tyrkiske og islamske verdier.

Ifølge Yavuz var europeiseringen av tyrkisk islam i utgangspunktet motivert av det handlingsrommet europeiseringen ga bevegelsen i forhold til den dogmatisk sekularistiske militærbyråkratiske eliten. Dette kan kanskje sees som et vellykket forsøk på å plukke opp tråden fra Özals periode. Men Yavuz fremholder videre at europeiseringen endret bevegelsens selvforståelse, slik at den har internalisert europeiske politiske verdier.

Erdogan har selv ved flere anledninger sammenlignet sitt parti med de europeiske kristelig-demokratiske partiene, og frem- holdt at partiets politikk er fundert i et islamsk verdigrunnlag. Samtidig kan nok Erdogan selv ha ønsket å beholde en noe uklar grenseoppdraging mot politisk islam, for å unngå å miste velgere til Saadet Partisi og for å holde de ulike fløyene av partiet samlet.

AKP videreførte ikke Erbakans program. Likevel blir partiet ofte beskrevet som «islamistisk», «moderat islamistisk» eller «mildt islamistisk» i norsk og internasjonal presse. Det gjelder også velrenommerte The Economist, som etter å ha støttet partiet på lederplass før parlamentsvalget sommeren 2007 kunne bringe nyheten om «Islamistenes triumf i Tyrkia». Her gjenspeiles retorikken fra Tyrkias dogmatisk illiberale sekularister, som ustanselig beskylder regjeringspartiet for å bære på en skjult agenda som truer republikkens sekulære konstitusjon, modernisering og demokrati.

Man bør imidlertid være varsom med å tillegge et politisk parti motiver på annet grunnlag enn hva de sier de vil giøre, og hva de faktisk giør. Det er klart at AKP hyppig refererer til islam i sin retorikk. Men det er som kjent mange partier i Vesten som benytter kristne religiøse referanser på en tilsvarende måte uten å bli kategorisert som kristenfundamentalistiske av den grunn. For at et parti skal kategoriseres som islamistisk i en politisk ideologisk forstand er det derfor rimelig å forutsette at partiet krever at lovverket - i en direkte eller indirekte forstand - funderes i islamsk lov.

Man kan etter dette synet ikke med rimelighet kategoriseres som islamist uten å eksplisitt eller implisitt ta avstand fra sekularisme som ideologi og statsprinsipp. Det har ikke Tyrkias regjeringsparti gjort. 
Erdogan har offentlig argumentert for at sekularisme som statsprinsipp er i pakt med islam.

Ledende talsmenn for partiet har også gjentatte ganger protestert mot å bli kategorisert som islamistisk, både i tyrkisk og i internasjonal presse. Senest i desember 2008 føyde AKPs utenrikspolitiske talsmann Egemen Bagıs følgende apropos til et åpent brev til redaktørene i The Economist: «Moreover, labelling the AK Party as "Islamist" is groundless. The AK Party is not Islamist, but a centrist-conservative, democratic political party.»

\section{Transformasjon eller konspirasjon?}

Som andre radikale ideologier står også dogmatisk islamisme seg dårlig i møte med politiske realiteter. Så hvorfor er det vanskeligere å akseptere at Erdogan og AKP har forlatt sitt utgangspunkt i politisk islam, enn å akseptere at vestlige sosialdemokratiske ledere har forlatt sine ideologiske utgangspunkt i radikal sosialisme?

Grunnen til at det er vanskelig å slå fast at AKP virkelig har akseptert det sekularistiske statsprinsippet, er at ethvert tyrkisk parti som i sitt program utfordrer dette etter konstitusjonen vil bli stengt og fratatt all makt. Den dogmatisk sekularistiske opposisjonen setter her AKP i en lei klemme: På den ene siden forbyr konstitusjonen partier å gå mot deres versjon av sekularismen. På den annen side fremholder de at man ikke kan stole på AKP når partiet erklærer at det ikke vil utfordre Tyrkias sekularisme, fordi det skal være en løgn partiet fremsetter for å unngå å bli stengt.

Det er ingen tvil om at AKP utfordrer den militærbyråkratiske elitens versjon av sekularismen. Men lar man konspirasjons- teoriene ligge, står man igjen med en kamp mellom to formuleringer av sekularismen, som grovt sett tilsvarer henholdsvis den etatistiske franske og den liberale amerikanske. De deler av AKPs program som fremheves som angrep på republikkens sekulære natur er snarere et angrep på den sekularistiske elitens kontroll over religiøse institusjoner og religiøse uttrykk i det offentlige rom. Dette kan ses som del av et bredere oppgjør med en seiglivet korporatistisk tradisjon i tyrkisk politikk. Denne konflikten har sine røtter i den over nevnte motstanden mot Atatürks europeisk inspirerte reformer i republikkens første tiår.

AKP fremstår i dag som et populistisk konservativt sentrumsparti, som er verdikonservativt ut fra tradisjonelle verdier som mange tyrkere anser som truet. Etter europeisk målestokk blir dermed partiets konservatisme illiberal; Erdogan har blant annet tatt til orde for å kriminalisere utroskap. Populismen trekker partiet mot venstre i fordelingspolitiske spørsmål. Dette er naturlig i et samfunn med store sosiale ulikheter og en forholdsvis svak velferdsstat. Samtidig gjennomfører partiet EU-tilpasninger som innebærer omfattende avreguleringer, og er på mange måter økonomisk sett et høyreparti.

Partiets konservatisme er preget av at Tyrkia er et tradisjonelt samfunn der religionen står sterkt. Den tyrkiske staten er som nevnt sekulær, mens det tyrkiske samfunnet i liten grad er sekularisert. Islam er i dag på mange måter mer fremtredende i hverdagslivet i sekularistiske Tyrkia enn i teokratiske Iran. I Iran har den dogmatiske islamismen skjøvet folk bort fra moskeene, mens i Tyrkia har den nesten like dogmatiske sekularismen hatt motsatt effekt. Ettersom korrupsjon og nepotisme i store 
deler av befolkningens øyne gjennomsyrer den etablerte politiske eliten i begge land, kompromitteres også de respektive regimenes ideologier. Denne utviklingen skremmer Tyrkias moderniserte og sekulariserte elite, som svarer med å stå enda steilere på sin illiberale versjon av sekularismen. Dette er en strategi som kan minne om et forsøk på å grave seg opp av en grop. Her ligger en av nøklene til AKPs suksess. Forbudet mot å bruke muslimsk hodetørkle i offentlige institusjoner, deriblant universiteter, har blitt en sentral symbolsak i denne konflikten. Siden AKP tok over regjeringsmakten i 2002 har det blitt stadig vanligere å se kvinnelige studenter som med hevet hode bryter dette forbudet, også på statlige universiteter i hovedstaden Ankara.

Etter partiets solide gjenvalg vedtok AKP i februar 2008, med støtte fra det sterkt nasjonalistiske Partiet for nasjonalistisk handling - Milliyetçi Hareket Partisi (MHP), en begrenset lovendring på dette feltet. Denne lovendringen åpnet for at kvinnelige studenter kunne få benytte et moderat hodetørkle på universitetene. Opposisjonspartiet CHP klaget imidlertid lovendringen inn for konstitusjonsdomstolen. Domstolen fant at lovendringen var i strid med prinsippet om sekularisme i konstitusjonen, og annullerte parlamentets vedtak i juni 2008.

Men dette gir ikke noe grunnlag for å slutte at noen stor andel av AKPs velgere ønsker seg en islamsk stat eller å avskaffe sekularisme som statsprinsipp. Man behøver verken være islamist, muslim eller religiøs for å mene at det er prinsipielt galt av staten å forby muslimske kvinner å bære hodetørkle på universiteter eller på offentlige kontorer. Ikke heller for å støtte at religiøse ledere fritt skal få velge hva de vil tematisere i sine prekener.

Om AKP har fremmet en ny tilnærming til spørsmålet om forholdet mellom stat og religion, bringer partiet ingen ny politisk kultur til tyrkisk politikk. AKP fremstår i denne sammenheng som et tradisjonelt autoritært parti, uten genuine demokratiske prosesser innad i partiorganisasjonen. Samtidig er partiet en sammensatt bevegelse, med stort ideologisk og verdimessig spenn. Det er en utbredt oppfatning at Erdogans personlige autoritet er en sentral faktor for å holde partiet samlet.

\section{Det tyrkiske demokratiets begrensninger}

Et etablert kriterie for å kategorisere en stat som demokratisk er at den skal ha gjennomgått to fredelige maktskifter på rad, i henhold til fastsatte demokratiske spilleregler. Som vi har sett, oppfyller Tyrkia dette kriteriet. Likevel blir det tyrkiske demokratiet kritisert for en rekke ganske grunnleggende mangler. For eksempel karakteriserer den ikkestatlige organisasjonen Freedom House, som hvert år gir karakterer til verdens staters styresett, fremdeles Tyrkia som «delvis fritt», til tross for at landet klassifiseres som et reelt demokrati. Det er flere svakheter ved Tyrkias demokrati som trekker ned her, både hva gjelder hvilke synspunkter som tillates representert, den makt de valgte representantene blir tildelt, og det samfunnsmessige miljøet det tyrkiske demokratiet virker i.

For det første er det altså klare begrensninger på hvilke synspunkter som kan representeres i det tyrkiske demokratiet. Det er i og for seg ikke uvanlig at det er lagt begrensninger på hvilken politikk som er tillatt å fremme innen rammene av en stats demokratiske system. Slike begrensninger 
har vi også i vestlige demokratier, illustrert ved norsk Høyesteretts dom mot det erklært rasistiske partiet Hvit Valgallianse i I997. Men i Tyrkia er disse begrensningene både flere og mer omfattende enn de man ser i demokratier som klassifiseres som liberale.

Begrensningene gjelder i hovedsak ytringer som anses å true statens territorielle integritet, ytringer som anses å true statens sekulære karakter og ytringer som kritiserer militærets rolle i staten. Terskelen for å bli dømt kan være lav; dagens statsminister Erdogan ble i i998 dømt og fengslet for å ha «initiert religiøst hat». Grunnen var at han offentlig hadde proklamert et dikt som inneholdt følgende strofer: «Moskeene er våre kaserner, kuplene våre hjelmer, minaretene våre bajonetter, de troende våre soldater. Denne hellige hæren vokter min religion.» Denne dommen førte også til at han for en periode var forhindret fra å ta statsministerposten etter AKPs valgseier i 2002.

I juli 2008 falt dommen $i$ en stengningssak mot regjeringspartiet AKP. Den tyrkiske konstitusjonsdomstolen har tradisjonelt vært dominert av dogmatisk sekularistiske krefter. Men i denne saken kom likevel et knapt flertall av dommerne til at partiet ikke skulle stenges, og avverget med det en dyp politisk krise i landet. Partiet ble imidlertid likevel funnet å ha bedrevet «antisekulær virksomhet», og ble idømt en reduksjon i offentlig støtte.

Sperregrensen på ti prosent bidrar også til å begrense hvem som representeres i det politiske systemet. Ved parlamentsvalget i 2002 ble det kurdiskdominerte Demokratiske folkepartiet - Demokratik Halk Partisi (DEHAP) det største partiet i samtlige provinser i Tyrkias sørøstlige region. Men da dette er et forholdsvis tynt befolket område, fikk partiet kun i overkant av seks prosent på landsbasis, og ble dermed ikke representert i parlamentet. Ved valget i 2007 stilte kandidatene til partiets etterfølger, Partiet for et demokratisk samfunn Demokratik Toplum Partisi (DTP), som uavhengige kandidater. Denne taktikken lykkes, og partiet fikk valgt inn de tyve representantene de etter loven trengte for å etablere en partigruppe i parlamentet.

Men den høye sperregrensen får også andre udemokratiske utslag. Ved parlamentsvalget i 2002 gikk 55 prosent av stemmene til partier som ikke nådde opp til sperregrensen. Det førte nødvendigvis til at de to partiene som passerte sperregrensen ble kraftig overrepresentert. Valgets vinner AKP fikk med en tredel av stemmene to tredeler av setene. Selv om regjeringspartiet gikk frem over I2 prosent ved parlamentsvalget i 2007 , mistet de seter fordi et tredje parti, nasjonalistpartiet MHP, denne gang passerte sperregrensen. For det andre er makten som blir gitt dem som vinner den demokratiske konkurransen om Tyrkias statsmakt begrenset. Slike begrensninger er en selvfølge i alle liberale demokratier, og regnes som en forutsetning for en liberal rettsstat. Men i Tyrkia gjelder begrensningene hele segmenter av den utøvende makten, deriblant sikkerhetspolitikken. Her har generalstaben hatt betydelig og tildels avgjørende innflytelse over politikken. Og siden generalstaben også har hatt makt til å definere hva som er sikkerhetspolitikk, har viktige deler av innenriks- og utenrikspolitikken blitt underlagt deres makt.

En annen aktuell begrensning ligger i konstitusjonsdomstolens myndighet til å annullere lovendringer den avgjør å være i 
strid med konstitusjonen. Slike mekanismer er vanlige i liberale rettstater, for å sikre konsistens i lovverket. Men den tyrkiske konstitusjonsdomstolen går lenger, og setter med det omfattende begrensninger på den lovgivende makten. Etter avgjørelsen om å forkaste lovendringen om studenters bruk av hodetørkle på universiteter ble konstitusjonsdomstolen beskyldt for å tilta seg rollen som et ikke-valgt overhus. Dommens begrunnelse ble endelig offentliggjort 2I. oktober, nær fem måneder etter dommen ble avsagt. Til alt overmål fremholdt konstitusjonsdomstolens president Hasım Kılıç og ytterligere en dommer i en dissens at dommen var i strid med konstitusjonen, og i tillegg også substansielt feilaktig. Dommens begrunnelse møtte også svært hard kritikk fra ledende akademikere innen statsrett, deriblant professor Ergun Özbudun. Han konkluderte at dommen innebærer at Tyrkia nå må skrive en ny konstitusjon for med rette å kunne kalles et reelt demokrati.

For det tredje er det svakheter ved det miljøet de demokratiske prosessene opererer i. Ytringer som er egnet til å fornærme den tyrkiske nasjonen, republikken eller statens institusjoner er fremdeles forbudt etter den tyrkiske straffelovens 『30I. Tyrkiske nasjonalister har på dette grunnlaget reist en lang rekke saker mot politikere, intellektuelle og journalister som har tillatt seg å utfordre nasjonale dogmer. Dette har blant annet rammet nobelprisvinneren i litteratur, Orhan Pamuk, selv om tiltalen mot ham riktignok ble frafalt. I en annen sak ble den profilerte skribenten Perihan Magden i 2006 frifunnet etter å ha forsvart en militærnekter i en kommentar. I fjor ble denne loven endret, slik at tiltaler må godkjennes av justisministeren. Dette avskjær- er nasjonalistenes muligheter til å benytte 『30I i propagandaøyemed, men paragrafen utgjør fremdeles en klar begrensning for ytringsfriheten. Videre er denne løsningen uheldig med tanke på ansvarsforholdet mellom den utøvende og den lovgivende makt.

Til sist er det verd å minne om at politisk vold fremdeles er til stede i Tyrkia. Både de nevnte militante gruppene, militante dogmatiske nasjonalister og organisert kriminalitet har stått bak politisk motiverte drap i løpet av det siste tiåret.

\section{Hva holder så Tyrkia tilbake?}

Det tyrkiske demokratiets svakheter må forstås i sin sammenheng. Noen problemer har ganske enkle årsaker, andre er mer sammensatte. Den høye sperregrensen med sine nær absurde utslag hører til de enklere. De partiene som har passert den, og som derfor har blitt grovt overrepresentert i parlamentet, har ikke sett sin interesse tjent med å senke den.

Den begrensede ytringsfriheten har mer sammensatte årsaker. En side av saken er at Tyrkias militærbyråkratiske elite har sittet på for mye politisk makt for lenge, og har kapslet seg inne med begrensninger i ytringsfriheten. Men det har helt riktig blitt påpekt at dette med militærets makt slår begge veier. Det har tidvis vært hendig for de valgte politikerne å kunne frasi seg ansvar med henvisning til at generalene ikke har godtatt nødvendige reformer. Dette skjer mye på samme måte som når man dumper belastningen for upopulære, men høyst nødvendige strukturtilpasninger over på EU.

De siste årenes reformer $\mathrm{i}$ retning av politisk liberalisering er også fremmet med henvisning til at de er nødvendige forutset- 
ninger for fremdrift i den lange og vanskelige prosessen mot et eventuelt tyrkisk EUmedlemskap. Flere av de gjenstående reformene på dette feltet er faktisk upopulære i et flertall av befolkningen, deriblant opphevelse av dødsstraff i fredstid og avskaffelse av den over nevnte straffelovens 『30I.

Dette må ses i sammenheng med at erfaringen fra det politisk friere syttitallet var at politisk liberalisering fører til splittelse, polarisering og ekstremisme. Etter den tid har det tyrkiske samfunnet vært under mer eller mindre konstant angrep fra et vidt spekter av militante ekstremistgrupper. Derfor har man i stor grad vært villige til å ofre en del politisk frihet for noe mer sikkerhet.

Svært mange tyrkere føler, delvis med rette, at de har blitt utsatt for doble standarder av europeere i forhold til den utfordringen Tyrkia har møtt fra militant kurdisk separatisme. Frustrasjonen dette skaper har naturlig nok fått nasjonalistiske uttrykk. Derfor blir alle reformer som på en eller annen måte begrenser nasjonalismens spillerom av mange ansett som høyt ufortjente konsesjoner til de samme europeerne.

Frykt for at et stadig sterkere AKP vil true Atatürks reformer var bare en av drivkreftene bak de store demonstrasjonene mot regjeringspartiet våren 2007. Like viktig var nok frykt for at AKP, gjennom sitt fortsatte engasjement for tyrkisk EUmedlemskap, vil gjennomføre reformer som truer de ideologiske og økonomiske interessene til den dogmatisk sekularistiske eliten, og deres ortodokse nasjonalistiske støttespillere.

Begrensningene på politiske og sivile friheter har også sammenheng med at det for svært mange tyrkere er uklart hvilke goder politisk liberalisering vil kunne by på. Mills tese om den frie ytringsfriheten som et absolutt gode er ikke selvforklarende i Tyrkia i dag. Bevissthet rundt problemer med maktkonsentrasjon og fordelene ved begrensninger i statens makt overfor borgerne er fremdeles lite utbredt.

Man kan kanskje si at i Tyrkia overskygger nasjonalismen den liberale rettsstatsideologien i samfunnets politiske kultur. Og selv om nasjonalismen riktignok bidrar til demokratiet med nødvendig nasjonal solidaritet, blir den liberale rettsstatsideologien svake stilling et problem for den videre demokratiseringsprosessen.

\section{Er islam en hemsko for demokratisering?}

Er det noe med muslimske samfunn som gjør dem mindre mottakelige for liberalt demokrati enn andre samfunn? Det har vært spekulert i om liberale rettsstatsprinsippers svake stilling i muslimske samfunn kan skyldes en monolittisk islamsk politisk kultur. Det har blant annet blitt vist til at profeten Muhammed som en guddommelig veiledet politisk leder har satt en standard for autoritært styresett.

Det foreligger minst to grunnleggende problemer med denne hypotesen. For det første kan det utledes en rekke ulike politiske konsekvenser ut fra en hvilken som helst religion, avhengig av preferansene til den som har makt til å utlede. Man kan like gjerne snu argumentet på hodet, og si at det er svakt utviklet liberal politisk kultur som muliggjør en politisk autoritær tolkning av islam.

Dernest er det ikke bare i muslimske samfunn det har vist seg vanskelig å etablere liberale demokratier. Som kjent har kun en begrenset andel av verdens kristne 
samfunn lyktes i dette. Det er dermed fristende å anta at det er andre kvaliteter ved våre vestlige samfunn enn religionen som gjør at liberalt demokrati som styreform har funnet fotfeste $i$ våre samfunn mens det ikke har gjort det $\mathrm{i}$ andre.

Så står det tyrkiske demokratiet som et eksempel til etterfølgelse? Som vi har sett er det flere faktorer som kan bidra til å forklare dets svakheter. Disse faktorene har i varierende grad vært til stede i stater som Hellas, Italia og Spania i vår nære fortid. Når vi ser etter de særlige faktorene som holder Tyrkia igjen i forhold til disse landene, peker en trang og stagnert nasjonalisme og en fastlåst konflikt om makt og statsideologi seg ut som langt sterkere kandidater enn islam.

\section{Tyrkia blir videre demokratisering} holdt gissel i kampen mellom to formuleringer av sekularismen. Dette er både en kamp om den tyrkiske nasjonen sjel og en kamp mellom en stagnert etatistisk elite og en ny tradisjonalistisk elite som har vokst ut av den politiske periferien.

AKP er neppe ut fra sin ideologi og sitt program noen naturlig forkjemper for en liberalisering av det tyrkiske demokratiet. Det er lite som tyder på at partiet markerer noe brudd med tradisjonell tyrkisk politisk kultur på dette punktet. Likevel kan partiets utfordring av den dogmatisk illiberale sekularismen vise seg å være et nødvendig skritt på veien mot å bli et demokratisk forbilde for samfunn med autoritære politiske tradisjoner.

\section{$\cdot f \cdot$}

I Jeg vil rette en stor takk til Einar Wigen, Kjetil Selvik, Gina Lende og tre anonyme fagfeller for nyttige innspill til tidligere utkast av denne artikkelen.

2 Med «liberalt demokrati» menes et styresett der borgernes grunnleggende friheter garanteres konstitusjonelt, i en rettstat bygget på maktfordelingsprinsipper. Slik sikres individets rettigheter overfor staten, og minoritetens rettigheter overfor majoriteten. Dette betyr selvsagt ikke at staten i et liberalt demokrati behøver å føre en politikk i tråd med liberalismen som politisk ideologi.

3 M. Hakan Yavuz (2004): «Is there a Turkish Islam? The Emergence of Convergence and Consensus», Journal of Muslim Minority Affairs, vol.24, no.2, 213-232

4 Tyrkisk Hizbullah har ingen tilknytning til libanesisk Hizbullah. Hizbullah betyr «Guds parti» på arabisk. Å betegne denne bevegelsen som «tyrkisk» er delvis misvisende, da bevegelsen først oppsto blant tyrkiske kurdere som en opposisjon til det marxistisk-inspirerte PKK.

5 Wilhelm Kavli (200I): «Tyrkias islamistparti stengt - for siste gang?», Morgenbladet nyhetskommentar 29.06 .2001

6 Meliha Benli Altunısık \& Özlem Tür (2005): «Turkey Challenges of Continuity and Change», Routledge Curzon. ISBN: 0-4I5-287I0-3, p.62-65

7 M. Hakan Yavuz (2004): «Is there a Turkish Islam? The Emergence of Convergence and Consensus», Journal of Muslim Minority Affairs, vol.24, no.2, 213-232

8 Today's Zaman (2007): «Erdogan rejects 'Malaysia' charges, moderate Islam», Today's Zaman news article 29.09 .2007

9 Egemen Bagis (2008): «Turkey and the world», The Economist Print Edition Letter to the Editor I8.I2.2008

Io Evren Çelik Wiltse (2008): «The Gordian Knot of Turkish Politics: Regulating Headscarf Use in Public», South European Society \& Politics, vol.13, no.2, pp.I95-2I5

II Laura Gradinariu (2007): «The banning of the Islamic Headscarf: Minority Protection or Persecution?», Insight Turkey, vol.ı, no.I, pp.82-9I

I2 See http://freedomhouse.org/

I3 Jamfør begrepet «liberal» $\mathrm{i}$ «liberalt demokrati» i note 2 over.

I4 Lars-Christian U. Talseth/Morgenbladet (2008): «Tyrkisk riksdag», Morgenbladet nyhetsartikkel oI.08.2008

I5 Zühtü Arslan (2008): «Can the Constitutional Court Change the Constitution?» Today's Zaman Op-Ed article 09.06.2008. See also Fehmi Koru (2008): «Judge me, judge me not», Today's Zaman Op-Ed article o9.06.2008

I6 Ali Aslan Kılıç \& Aysegül Aybar/ Today's Zaman (2008): «Top court decision cripples Parliament», Today's Zaman news article 23.10.2008

I7 Ergun Özbudun (2008): «New constitution is now a must», Today's Zaman Op-Ed article 26.Io.2008

I8 Ercan Yavuz/ Today's Zaman (2008): «Academics find amendments to 301 unsatisfactory», Today's Zaman news article 05.05 .2008 